\title{
Performance and health implication of feeding Fungi treated cocoa pod husk meal on broiler
}

\author{
Olawale Mojeed Akanbi®
}

\begin{abstract}
Background: The utilization parameters of Marshall broiler fed fungi treated cocoa pod husk meal (FTCPHM) with respect to growth performance and health implication were evaluated. Four diets were formulated using FTCPHM at 0, 5, 10 and 15\% inclusion levels and designated as T1. T2, T3 and T4 respectively. Ninety-Six day old Marshall broiler comprising 24 birds per treatment with eight birds serving as a replicate in a Completely Randomized design (CRD).

Results: It was revealed that T1, T2 and T3 utilized their diets for total weight gain, feed conversion ratio and lowest mortality compared to T4. The live weight, head, breast and shank were the only parameters that showed significant $(P<0.05)$ differences in the carcass measurement with highest values observed in T2 $(1.92 \mathrm{~kg})$, T1 $(30.30$ $\mathrm{g} / \mathrm{kg}), \mathrm{T} 1(213.49 \mathrm{~g} / \mathrm{kg})$ and T4 $(46.74 \mathrm{~g} / \mathrm{kg})$ respectively. While only the relative organ weight of the liver and pancreas were significantly $(P<0.05)$ affected. All parameters of the hematology were significantly $(P<0.05)$ influenced by the diet except White blood cell. Consequently, the serum biochemical indices were also significant $(P<0.05)$ in high-density lipoprotein, low-density lipoprotein, albumin and globulin.
\end{abstract}

Conclusion: It was therefore concluded that inclusion of above 10\% FTCPHM may have an adverse effect on the performance and health of the birds.

Keywords: Cocoa pod husk, Fungi, Hematology, HDL, LDL, Performance

\section{Introduction}

The animal protein intake of an average individual in most African and Pacific countries falls between 8 and $15 \mathrm{~g}$ per day (Ogunsipe et al. 2017), which is far below $65 \mathrm{~g}$ per day; of this, $36 \mathrm{~g}$ (i.e. $55.3 \%$ ) should come from animal sources recommended by FAO (2008). This could partly be as a result of high cost of finished feed due to increase in the price of conventional feed ingredients and consequent rise in the cost of animal protein beyond the purchasing power of most people in these regions (Oloruntola et al. 2016a). Since feed cost ranged between 60 to $65 \%$ of the total cost of production for monogastric animals under intensive system (Nworgu et al. 1999; Adegbenro et al. 2017), it is believed that replacing some of the expensive and import-dependent

Correspondence: akanbiom@futa.edu.ng

Department of Animal Production and Health, Federal University of Technology, Akure, Ondo State, Nigeria conventional feed ingredients in part or wholly will go a long way to reducing the production cost and increase the animal protein intake in Nigeria.

Processed by-products of cocoa harvesting industry have been reported as a suitable replacement for some conventional feedstuff in monogastric production (Eghosa et al. 2010; Ogunsipe et al. 2017). Cocoa pod husk forms about $80 \%$ of cocoa fruit and between 0.8 and 1.0 million tons of cocoa pod husk are generated annually in Nigeria, most of which are considered a waste except for the very negligible quantity being used in local soap making (Adeyeye et al. 2016).

Nutritional value of cocoa pod is relatively low as it is low in crude protein $(9.14 \%)$ and high crude fiber (35.78\%). It also contains anti-nutrients such as theobromine (2.64\%), caffeine (1.14\%) and tannin 0.917\%) (Adeyeye et al. 2016). Several methods have been adopted in the treatment and processing of cocoa pod husk meal for the purpose of animal feed formulation. 
Some of these methods include hot-water treatment (Adegbola and Omole 1973); alkali treatment (Isika et al. 2012); enzyme (mannanase) treatment (Bedford 2000; Zakaria et al. 2008); urea treatment (Olubamiwa and Akinwale 2000; Iyayi et al. 2001); fungal treatment (Adamafio et al. 2011) and microbial detheobromination (Mazzafera 2002). These treatment procedures are somehow expensive and complex for the local farmers to adopt, hence the need to device cheaper and less cumbersome methods that will be adoptable by farmers for effective utilization of cocoa pod husks in animal feeds.

Omoifo (2011) reported that Rhizopus stolonifer, a Zygomycete has a filamentous growth habit. Its filaments are coenocytic, that is, they are non-septate. It is the only fungus yet known to produce rhizoids which penetrate the substratum in order to obtain nutrients. The rhizoids also serve as support. Opposite the rhizoids, a sporangiophore juts into the atmosphere and this terminates in a club-shaped collume lumen closed within the sporangial wall. Consequently, this study is geared towards testing the nutritionally enhanced cocoa pod husk meal with Rhizopus stolonifer in vivo using Marshall broiler chicken with a view to determining the utilization of this product when included in their diets at varying levels.

\section{Material and methods}

\section{Experimental location}

The feeding trial was carried out at the Poultry Unit of the Livestock Section, Teaching and Research Farm, The Federal University of Technology, Akure (FUTA). The University (FUTA) is geographically located between latitude $7^{\circ} 5^{\prime} \mathrm{N}$ and longitude $5^{\circ} 15^{\prime} \mathrm{E}$ at an altitude of $370 \mathrm{~m}$ above sea level (Oyinloye 2013). The University is also located in the humid rain forest zone of Western Nigeria with tropical climate of two seasons: rainy season (April-October) and dry season (November - March) with a mean annual rainfall of $829 \mathrm{~mm}$, an average annual temperature of $12.0{ }^{\circ} \mathrm{C}$ and an average relative humidity of $86 \%$ which characterize the climatic area (http://en.climate-data. org/location/674260/).

\section{Collection and processing of cocoa (Theobroma cacao) pod husks}

Freshly broken composite cocoa pods were obtained from cocoa farms plantations located in Idanre, Ondo State. The broken cocoa pods were washed, milled and fermented in vitro using Rhizopus stolonifer fungi for 14 days under room temperature. Thereafter, the fermented cocoa pod husk meal was dried, milled and sample analyzed for proximate composition along with the unfermented samples.

\section{Cocoa pod husk fermentation method using a starter culture}

Fermentation of cocoa pod husk meal (CPHM) was done to reduce the theobromine and fiber contents that could inhibit the utilization of the pod meal in the birds. CPHM was fermented through solid state fermentation during each period of fermentation after milling. Ten (10) grams of urea was dissolved in $100 \mathrm{l}$ of water which was used to moist the sterilized CPHM. One liter of the prepared inoculums of the starter culture of Rhizopus stolonifer was used to inoculate the urea treated CPHM and kept in a tray in an incubating chamber. The fermentation of the cocoa pod husk meal was completed on the 14th day, followed by sun drying the substrates for five to seven days to inactivate the microorganism.

\section{Dietary treatment}

One basal diet was formulated to meet the nutrient requirement of broiler chicks according to National Research Council (1994) recommendation. The fermented cocoa pod husks (FCPH) meal was included as an independent ingredient at $0 \%, 5 \%, 10 \%, 15 \%$ levels in the diets and were designated as T1, T2, T3 and T4, respectively. The dietary formulae were balanced in such a way that the four diets were isonitrogenous and isocaloric. The same procedure was adopted for finisher diets. The formulae for both starter and finisher diets are presented in Tables 1 and 2, respectively.

\section{Chicks arrangement and management}

One hundred (100) day-old Marshall broiler chicks were procured from Obasanjo farms in Ibadan, Oyo State, Nigeria out of which ninety- six (96) were assigned to four (4) dietary treatments of three (3) replicates of eight (8) chicks per replicate. The design of the experiment was a Completely Randomized Design.

\section{Chicks arrangement and management}

One hundred (100) day-old Marshall broiler chicks were procured from Obasanjo farms in Ibadan, Oyo State, Nigeria out of which ninety- six (96) were assigned to four (4) dietary treatments of three (3) replicates of eight (8) chicks per replicate. The design of the experiment was a Completely Randomized Design.

\section{Data collection}

Growth performance and feed intake were measured and summarized on a weekly basis. At the end of each week, the total feed consumed and the final weight was recorded and from the data obtained, the feed conversion ratio (FCR) was calculated. 
Table 1 Gross composition of the experimental starter diets

\begin{tabular}{|c|c|c|c|c|}
\hline \multicolumn{2}{|l|}{ INGREDIENTS } & \multicolumn{3}{|c|}{ TREATMENTS } \\
\hline & $1(0 \%)$ & $2(5 \%)$ & $3(10 \%)$ & $4(15 \%)$ \\
\hline Maize & 51.30 & 46.30 & 42.30 & 42.30 \\
\hline Wheat offal & 4.00 & 4.00 & 5.00 & 5.00 \\
\hline Soybean meal & 21.00 & 21.00 & 19.00 & 16.00 \\
\hline Groundnut cake & 13.00 & 13.00 & 13.00 & 11.00 \\
\hline Fish meal & 5.00 & 5.00 & 5.00 & 5.00 \\
\hline FCPHM (21\%) & 0.00 & 5.00 & 10.00 & 15.00 \\
\hline Lysine & 0.10 & 0.10 & 0.10 & 0.10 \\
\hline Methionine & 0.10 & 0.10 & 0.10 & 0.10 \\
\hline DCP & 2.00 & 2.00 & 2.00 & 2.00 \\
\hline Limestone & 1.00 & 1.00 & 1.00 & 1.00 \\
\hline Premix & 0.25 & 0.25 & 0.25 & 0.25 \\
\hline Salt & 0.25 & 0.25 & 0.25 & 0.25 \\
\hline Vegetable oil & 2.00 & 2.00 & 2.00 & 2.00 \\
\hline Total & 100.00 & 100.00 & 100.00 & 100.00 \\
\hline \multicolumn{5}{|l|}{ Calculated } \\
\hline ME (MJ/kg) & 12.59 & 12.61 & 12.62 & 12.62 \\
\hline Crude Protein (\%) & 23.10 & 23.14 & 23.19 & 23.22 \\
\hline Calcium (\%) & 1.17 & 1.18 & 1.18 & 1.17 \\
\hline Phosphorus (\%) & 0.73 & 0.74 & 0.75 & 0.74 \\
\hline Lysine (\%) & 1.28 & 1.47 & 1.63 & 1.72 \\
\hline Methionine (\%) & 0.48 & 0.49 & 0.49 & 0.48 \\
\hline
\end{tabular}

FCPHM Fermented Cocoa Pod Husk Meal, DCP Dicalcium Phosphate, ME Metabolizable Energy

\section{Birds slaughtering and blood collection}

The birds were fastened $12 \mathrm{~h}$ before the collection of blood early in the morning. Six birds were randomly selected per treatment to determine the carcass and relative organ characteristics, hematological parameters, serum parameters and antioxidants activities. The birds were stunned before slaughtering in compliance with World Poultry Association guidelines. They were bled by severing the jugular vein and carotid artery and blood samples were collected during slaughtering at the end of the experimental period. The blood samples for hematological studies were collected in ethylenediaminetetraacetic acid (EDTA) bottles and blood meant for serum biochemical indices were collected in a test tube without anticoagulants and placed in the slanted form.

\section{Carcass and relative organ measurements}

The carcasses were scalded at $65^{\circ} \mathrm{C}$ in a water bath for about 30s before defeathering. The dressed chickens were eviscerated. The measurement of the carcass traits (dressed weight (\%), eviscerated weight (\%), thigh, drumstick, shank, breast, back, neck, wing and head) were taken before dissecting out the organs. The organs measured were the liver, lungs, pancreas, heart, spleen, belly
Table 2 Gross composition of the experimental finisher diets

\begin{tabular}{|c|c|c|c|c|}
\hline \multicolumn{2}{|l|}{ INGREDIENTS } & \multicolumn{3}{|c|}{ TREATMENTS } \\
\hline & $1(0 \%)$ & $2(5 \%)$ & $3(10 \%)$ & $4(15 \%)$ \\
\hline Maize & 59.50 & 56.50 & 55.00 & 52.00 \\
\hline Soybean meal & 14.50 & 14.00 & 11.00 & 9.50 \\
\hline Groundnut cake & 16.30 & 14.80 & 15.30 & 14.80 \\
\hline Fish meal & 3.00 & 3.00 & 3.00 & 3.00 \\
\hline FCPHM (21\%) & 0.00 & 5.00 & 10.00 & 15.00 \\
\hline Lysine & 0.10 & 0.10 & 0.10 & 0.10 \\
\hline Methionine & 0.10 & 0.10 & 0.10 & 0.10 \\
\hline $\mathrm{DCP}$ & 1.00 & 1.00 & 1.00 & 1.00 \\
\hline Limestone & 2.00 & 2.00 & 2.00 & 2.00 \\
\hline Premix & 0.25 & 0.25 & 0.25 & 0.25 \\
\hline Salt & 0.25 & 0.25 & 0.25 & 0.25 \\
\hline Vegetable oil & 3.00 & 3.00 & 2.00 & 2.00 \\
\hline Total & 100.00 & 100.00 & 100.00 & 100.00 \\
\hline \multicolumn{5}{|l|}{ Calculated } \\
\hline ME (MJ/kg) & 13.36 & 13.49 & 13.43 & 13.56 \\
\hline Crude Protein (\%) & 20.93 & 20.88 & 20.80 & 20.78 \\
\hline Calcium (\%) & 1.06 & 1.06 & 1.06 & 1.06 \\
\hline Phosphorus (\%) & 0.41 & 0.42 & 0.42 & 0.43 \\
\hline Lysine (\%) & 1.03 & 1.19 & 1.32 & 1.47 \\
\hline Methionine (\%) & 0.42 & 0.43 & 0.43 & 0.43 \\
\hline
\end{tabular}

FCPHM Fermented Cocoa Pod Husk Meal, DCP Dicalcium Phosphate, ME Metabolizable Energy

fat and gizzard. All the carcass traits, except the dressed and eviscerated weights, were expressed as percentages of the live weight while the organs were expressed in $\mathrm{g} /$ $\mathrm{kg}$ body weight.

\section{Statistical analysis}

All data that were collected were subjected to One Way Analysis of Variance (ANOVA) of SPSS (version, 23.0). Significant treatment means were compared using New Duncan's Multiple Range Test of the same package.

\section{Results}

Table 3 shows the performance traits of broiler fed varying levels of fermented cocoa pod husk meal (FCPHM). Significant $(P<0.05)$ differences were observed in total feed intake (TFI), average daily feed intake (ADFI), feed conversion ratio (FCR) and mortality. T2, T3 and T4 showed the highest significant values of $2948.53 \mathrm{~g}$, $3041.98 \mathrm{~g}, 2862.25 \mathrm{~g}$ and $70.20 \mathrm{~g}, 72.43 \mathrm{~g}, 68.15 \mathrm{~g}$ in TFI and ADFI respectively while the lowest values were recorded in T1 with values of $2364.13 \mathrm{~g}$ and $56.29 \mathrm{~g}$ respectively. FCR was best in T1 and T2 with values of 1.54 and 1.66 respectively compared to the rest of the treatments. Mortality was highest in T4 with $0.69 \%$ and lowest in T2. Similarly, final weight (FWT), weight gain 
Table 3 Performance traits of broiler fed fungi treated cocoa pod husk meal

\begin{tabular}{|c|c|c|c|c|c|}
\hline Parameters & $\mathrm{T} 1$ & $\mathrm{~T} 2$ & T3 & T4 & SEM \pm \\
\hline Initial Weight (g) & 30.80 & 30.68 & 30.76 & 30.55 & 0.21 \\
\hline Final Weight (g) & 1582.43 & 1804.95 & 1790.85 & 1409.21 & 72.69 \\
\hline Weight Gain (g) & 1551.63 & 1774.30 & 1760.08 & 1378.66 & 72.79 \\
\hline Total Feed Intake (g) & $1364.13^{b}$ & $2948.53^{\mathrm{a}}$ & $3041.98^{\mathrm{a}}$ & $2862.25^{\mathrm{a}}$ & 99.62 \\
\hline Ave. Daily Weight Gain (g) & 36.94 & 42.25 & 41.91 & 32.83 & 1.73 \\
\hline Ave. Daily Feed Intake (g) & $56.29^{b}$ & $70.20^{\mathrm{a}}$ & $72.43^{\mathrm{a}}$ & $68.15^{\mathrm{a}}$ & 2.37 \\
\hline Feed Conversion Ratio & $1.54^{\mathrm{a}}$ & $1.66^{\mathrm{a}}$ & $1.74^{\mathrm{ab}}$ & $2.10^{\mathrm{b}}$ & 0.79 \\
\hline Mortality (\%) & $0.35^{\mathrm{ab}}$ & $0.23^{b}$ & $0.35^{\mathrm{ab}}$ & $0.69^{\mathrm{a}}$ & 0.72 \\
\hline
\end{tabular}

abc means on the same row with different superscript are significantly $(P<0.05)$ different

(WG) and average daily weight gain (ADWG) were not significantly $(P>0.05)$ different but differed numerically with T2 having the highest values of $1804.95 \mathrm{~g}, 1714.30 \mathrm{~g}$ and $42.25 \mathrm{~g}$ respectively.

The carcass traits measurement is shown in Table 4, where no significant $(P>0.05)$ differences were observed in the parameters except the live weight (LWT), head, breast and shank. T2 had the highest and lowest statistical value of $1.92 \mathrm{~kg}$ and $25.21 \mathrm{~g} / \mathrm{kg}$ in LWT and head respectively compared to the rest of the group and T4 having the lowest value of $1.57 \mathrm{~kg}$ in LWT and the highest statistical value of $30.16 \mathrm{~g} / \mathrm{kg}$ in head which is not significant $(P>0.05)$ from T1 and T3. The breast recorded the highest value of $213.49 \mathrm{~g} / \mathrm{kg}$ in $\mathrm{T} 1$ and lowest in T4 with $176.26 \mathrm{~g} / \mathrm{kg}$. Also, T4 had the highest value of $46.74 \mathrm{~g} / \mathrm{kg}$ in shank while T2 had the lowest value of 38.95 .

Relative organs weight results are shown in Table 5 . There were no significant $(P>0.05)$ differences in the parameters except the liver and pancreas. The liver showed the highest significant values in T1, T2 and T4 with $24.96,23.70$ and $22.94 \mathrm{~g} / \mathrm{kg}$ respectively compared

Table 4 Carcass traits measurement of broiler fed fungi treated cocoa pod husk meal

\begin{tabular}{llllll}
\hline Parameters & T1 & T2 & T3 & T4 & SEM \pm \\
\hline Live Wgt (kg) & $1.75^{\mathrm{ab}}$ & $1.92^{\mathrm{a}}$ & $1.69^{\mathrm{ab}}$ & $1.57^{\mathrm{b}}$ & 0.56 \\
Dressed Wgt (\%) & 89.17 & 89.48 & 90.41 & 91.06 & 0.55 \\
Eviscerated Wgt (\%) & 77.72 & 74.92 & 75.77 & 74.41 & 0.76 \\
Head $(\mathrm{g} / \mathrm{kg})$ & $30.30^{\mathrm{a}}$ & $25.21^{\mathrm{b}}$ & $28.37^{\mathrm{ab}}$ & $30.16^{\mathrm{a}}$ & 0.74 \\
Drumstick $(\mathrm{g} / \mathrm{kg})$ & 92.78 & 91.07 & 78.63 & 89.61 & 4.09 \\
Thigh $(\mathrm{g} / \mathrm{kg})$ & 117.44 & 98.08 & 108.06 & 97.68 & 3.35 \\
Wing $(\mathrm{g} / \mathrm{kg})$ & 79.84 & 76.67 & 81.10 & 76.57 & 1.19 \\
Back $(\mathrm{g} / \mathrm{kg})$ & 170.78 & 161.93 & 159.11 & 158.25 & 4.57 \\
Breast $(\mathrm{g} / \mathrm{kg})$ & $213.49^{\mathrm{a}}$ & $194.71^{\mathrm{ab}}$ & $190.06^{\mathrm{ab}}$ & $176.26^{\mathrm{b}}$ & 5.28 \\
Shank $(\mathrm{g} / \mathrm{kg})$ & $42.65^{\mathrm{ab}}$ & $38.95^{\mathrm{b}}$ & $43.86^{\mathrm{ab}}$ & $46.74^{\mathrm{a}}$ & 1.18 \\
Neck $(\mathrm{g} / \mathrm{kg})$ & 37.33 & 37.74 & 40.70 & 38.18 & 1.18 \\
\hline
\end{tabular}

abc means on the same row with different superscript are significantly $(P<0.05)$ different, Wgt: Weight to T3 with the lowest value of $20.24 \mathrm{~g} / \mathrm{kg}$. T3 had the lowest statistical value of $4.25 \mathrm{~g} / \mathrm{kg}$ in pancreas and not significantly $(P>0.05)$ differed from $\mathrm{T} 1(4.56 \mathrm{~g} / \mathrm{kg})$ and T2 $(5.27 \mathrm{~g} / \mathrm{kg})$ compared to the highest value recorded in T4 $(6.08 \mathrm{~g} / \mathrm{kg})$ which is also not significantly $(P>0.05)$ different from $\mathrm{T} 1$ and $\mathrm{T} 2$.

Table 6 shows the hematological parameters of the birds. It was revealed from the table that significant $(P<0.05)$ differences were observed in all parameters except the white blood cell (WBC) which is numerically higher in T1 $\left(4.33 \times 10^{9}\right)$. Packed cell volume $(\mathrm{PCV})$, red blood cell (RBC), mean cell hemoglobin concentration $(\mathrm{MCHC})$ and hemoglobin $(\mathrm{Hb})$ were statistically highest in T2 and T3 with values of $31.67 \%$ and $31.50 \%, 1.58 \times 10^{6} / 1$ and $1.57 \times 10^{6} / \mathrm{l}, 33.23 \mathrm{~g} / \mathrm{dl}$ and $33.31 \mathrm{~g} / \mathrm{dl}$, and $10.56 \mathrm{~g} / \mathrm{dl}$ and $10.49 \mathrm{~g} / \mathrm{dl}$, respectively. Mean corpuscular hemoglobin $(\mathrm{MCH})$ and mean cell volume (MCV) were highest in T4 with values of $350.00 \mathrm{fl}$ and $116.67 \mathrm{Pg} / \mathrm{cell}$ compared to the rest of the treatments statistically.

The serum biochemical indices are shown in Table 7 . Significant $(P<0.05)$ differences were observed in high-density lipoprotein (HDL), low-density lipoprotein (LDL), albumin and globulin. Cholesterol, total protein, aspartate aminotransferase (AST) and alanine aminotransferase (ALT) were not significantly $(P>0.05)$ different. T3 had the highest HDL value of $3.18 \mathrm{Mmol} / \mathrm{l}$

Table 5 Relative organs weight of broiler fed fungi treated cocoa pod husk meal

\begin{tabular}{llllll}
\hline Parameters $(\mathrm{g} / \mathrm{kg})$ & $\mathrm{T} 1$ & $\mathrm{~T} 2$ & $\mathrm{~T} 3$ & $\mathrm{~T} 4$ & SEM \\
\hline Liver & $24.96^{\mathrm{a}}$ & $23.70^{\mathrm{a}}$ & $20.24^{\mathrm{b}}$ & $22.94^{\mathrm{ab}}$ & 0.61 \\
Spleen & 1.52 & 1.16 & 0.98 & 0.97 & 0.10 \\
Heart & 5.90 & 5.36 & 5.62 & 5.55 & 0.19 \\
Gizzard & 22.32 & 23.02 & 22.31 & 23.13 & 0.89 \\
Proventriculus & 2.94 & 2.31 & 2.91 & 2.26 & 0.19 \\
Pancreas & $4.56^{\mathrm{ab}}$ & $5.27^{\mathrm{ab}}$ & $4.25^{\mathrm{b}}$ & $6.08^{\mathrm{a}}$ & 0.28 \\
Belly Fat & 14.90 & 16.92 & 12.33 & 14.28 & 0.86 \\
Lungs & 5.39 & 5.44 & 5.45 & 5.63 & 0.11 \\
\hline
\end{tabular}

$a b c$ means on the same row with different superscript are significantly $(P<0.05)$ different 
Table 6 Hematological parameters of broiler fed fungi treated cocoa pod husk meal

\begin{tabular}{llllll}
\hline Parameters & T1 & T2 & T3 & T4 & SEM \pm \\
\hline PCV $(\%)$ & $27.00^{\mathrm{b}}$ & $31.67^{\mathrm{a}}$ & $31.50^{\mathrm{a}}$ & $26.67^{\mathrm{b}}$ & 0.64 \\
RBC $\left(\times 10^{6} / \mathrm{l}\right)$ & $1.83^{\mathrm{a}}$ & $1.58^{\mathrm{a}}$ & $1.57^{\mathrm{a}}$ & $1.07^{\mathrm{b}}$ & 0.09 \\
MCHC $(\mathrm{g} / \mathrm{dl})$ & $32.43^{\mathrm{b}}$ & $33.23^{\mathrm{a}}$ & $33.31^{\mathrm{a}}$ & $32.50^{\mathrm{b}}$ & 0.11 \\
MCV (fl) & $169.70^{\mathrm{b}}$ & $203.98^{\mathrm{b}}$ & $221.04^{\mathrm{b}}$ & $350.00^{\mathrm{a}}$ & 24.60 \\
MCH (Pg/cell) & $56.57^{\mathrm{b}}$ & $68.00^{\mathrm{b}}$ & $73.69^{\mathrm{b}}$ & $116.67^{\mathrm{a}}$ & 8.20 \\
Hb (g/dl) & $9.00^{\mathrm{b}}$ & $10.56^{\mathrm{a}}$ & $10.49^{\mathrm{a}}$ & $8.89^{\mathrm{b}}$ & 0.22 \\
WBC $\left(\times 10^{9} / \mathrm{l}\right)$ & 4.33 & 3.97 & 2.85 & 3.37 & 0.28
\end{tabular}

$a b c$ means on the same row with different superscript are significantly $(P<0.05)$ different, $P C V$ Packed Cell Volume, RBC Red Blood Cell, MCHC Mean Cell Hemoglobin Concentration, MCV Mean Cell Volume, MCH Mean

Corpuscular Hemoglobin, $\mathrm{Hb}$ Hemoglobin, WBC White Blood Cell

compared to T4 with the lowest value of $2.59 \mathrm{Mmol} / \mathrm{l}$. LDL was highest in T4 (1.33Mmol/l) and lowest in T1 and T3 with the same value of $0.16 \mathrm{Mmol} / \mathrm{l}$. The albumin recorded the highest statistical values in T1, T2 and T3 with $12.39 \mathrm{~g} / \mathrm{l}$, $12.67 \mathrm{~g} / \mathrm{l}$ and $12.63 \mathrm{~g} / \mathrm{l}$ respectively compared to the lowest recorded in T4 $(8.48 \mathrm{~g} / \mathrm{l})$. Similarly, the highest value for globulin was observed in $\mathrm{T} 4(38.07 \mathrm{~g} / \mathrm{l})$ while the lowest value was observed in T2 $(22.55 \mathrm{~g} / \mathrm{l})$.

\section{Discussion}

Based on the result of findings of the current study, the inclusion of FTCPHM above 10\% could impair the performance of broilers as significant differences was observed in TWG, ADWG and FCR and mortality which is in agreement with Teguia et al. (2004) who reported that $10 \%$ substitution of cocoa husk in replacement for maize showed significantly faster growth than control and birds fed above $20 \%$ and when compared with the control birds recorded lower body weight and poor efficiency of feed utilization. However, this study does not agree with the report of Nortey et al. (2015) who reported no effect on the performance characteristics of broilers with

Table 7 Serum biochemical indices of broiler fed fungi treated cocoa pod husk meal

\begin{tabular}{llllll}
\hline Parameters & T1 & T2 & T3 & T4 & SEM \pm \\
\hline Cholesterol (Mmol/l) & 2.17 & 2.51 & 2.56 & 2.98 & 0.13 \\
HDL (Mmol/l) & $2.92^{\mathrm{ab}}$ & $2.90^{\mathrm{ab}}$ & $3.18^{\mathrm{a}}$ & $2.59^{\mathrm{b}}$ & 0.09 \\
LDL (Mmol/l) & $0.16^{\mathrm{b}}$ & $0.70^{\mathrm{ab}}$ & $0.16^{\mathrm{b}}$ & $1.33^{\mathrm{a}}$ & 0.15 \\
T. Protein (g/l) & 42.56 & 35.22 & 41.61 & 46.54 & 1.95 \\
Albumin (g/l) & $12.39^{\mathrm{a}}$ & $12.67^{\mathrm{a}}$ & $12.63^{\mathrm{a}}$ & $8.48^{\mathrm{b}}$ & 0.55 \\
Globulin (g/l) & $30.16^{\mathrm{ab}}$ & $22.55^{\mathrm{b}}$ & $28.98^{\mathrm{ab}}$ & $38.07^{\mathrm{a}}$ & 2.28 \\
AST (ui/l) & 174.12 & 172.48 & 181.78 & 179.25 & 2.42 \\
ALT (ui/l) & 38.24 & 38.32 & 38.55 & 40.40 & 0.42
\end{tabular}

abc means on the same row with different superscript are significantly $(P<0.05)$ different, HDL High-Density Lipoprotein, LDL Low-Density Lipoprotein, $T$ Total, AST Aspartate Aminotransferase, ALT

Alanine Aminotransferase inclusion levels of $0 \%, 5 \%, 7.5 \%$ and $10 \%$. The decrease in the weight gain of the birds fed 15\% FTCPHM is suggested to be caused by poor utilization of nutrients by the birds, especially as the crude fiber increases. This is also a likelihood of theobromine and/ or other anti-nutrients binding or locking up essential nutrients thereby impairing their bioavailability to the birds thus impeding the overall growth of the birds. The optimum feed utilization was observed in birds fed 0\%- $10 \%$ FCPHM which had a better FCR compared to values for $15 \%$ inclusion level of FCPHM. This is in agreement with Hamzat and Babatunde (2006) and Adeyemo et al. (2015) that beneficial effects could be achieved in broiler starter and finisher diets if cocoa bean seed (CBS) is included at $10 \%$ level of inclusion beyond which weight gain was decreased and poorer feed to gain ratio resulted.

Adegbenro et al. (2017) reported that carcass has been shown to be an important tool in determining the connection between the wholesale or processed birds and the quality of product yield for the system is fixed by a predetermined quantity of kilogram carcass of the final product of broiler. Sarojini (2005) reported that organs are body parts, composed of several types of tissues capable of carrying out specialized functions. The breast, muscles and drumsticks are the most economically important portion of the carcass and also provide the greatest part of edible meat in broilers (Asafa et al, 2012). The LWT, head, breast, shank, liver and pancreas were influenced only by the dietary treatments. $0 \%, 5 \%$ and 10\% FCPHM inclusion recorded highest values. This observation, therefore, implies that the dressed weight of chicken may not necessarily be directly proportional to the performance traits. All values obtained are in ranges with Teguia et al. (2004) and Adegbenro et al. (2017).

Generally, an increase in the amount of soluble fiber in the diet results in the lowering of belly fat in broilers (Saki et al. 2011; Shirzadi et al. 2009). This may be because soluble $\mathrm{CPH}$ in the GIT can cause a reduction in nutrients, particularly fat absorption. In this trial, no differences in belly fat content were found among birds on different treatments. It could be the type of fiber in $R h i$ zopus stolonifer-detheobromized CPHM was either nonsoluble or if soluble was not enough to elicit the effect of a reduction in belly fat.

In addition, the relative organ weight measured in this study indicated that there was no visceral damage due to the intake of FTCPHM and internal systems were functionally normal. This study, therefore, suggests that the live weight of the birds is a function of the dietary treatment effects.

Hematological parameters have been associated with health indices and are of diagnostic significance in the routine clinical evaluation of the state of health (Saliu 
et al. 2012). Reports also stated that PCV, $\mathrm{HB}$ and $\mathrm{MCH}$ were major indices for evaluating circulating avian erythrocytes and were very significant in the diagnosis of anemia and also served as useful indices of bone marrow capacity to produce red blood cells as in mammals (Chineke et al. 2006). Nutrition also has a strong influence on the hematological traits and values of these traits are indicators of nutritional status of the animals (Oloruntola et al. 2016b; Adeyeye et al. 2017; Oloruntola et al. 2018). Akanbi (2019) also reported that hematological constituents reflect the responsiveness of the animal to its environments which includes feed and feeding. In this study, values of all the hematological indices do not fall within the normal ranges of values except $\mathrm{Hb}$ with values of $8.89-10.56 \mathrm{~g} / \mathrm{dl}$ compared to normal ranges of values reported by Swenson (1977) of $6.5-9.0 \mathrm{~g} / \mathrm{dl}$. It could, however, be observed that 5\% and 10\% FTCPHM were over the range except for 0\% and 15\% FCPHM. The PCV, RBC and WBC values obtained in this study $26.67-31.67 \%, 1.07-1.83 \times 10^{6} / \mathrm{l}$, and $2.85-4.33 \times 10^{9} / \mathrm{l}$, respectively were lower than the range of values of 30 $33 \%, 2.5-3.2 \times 10^{6} / \mathrm{l}$, and $9-13 \times 10^{9} / \mathrm{l}$, respectively reported by Swenson (1977). The FTCPHM did not lead to a boost in the WBC but lowered it counts in the experimental broiler chicken. This further reiterates its immunomodulation ability to be low since WBC is concerned in combating disease-causing organisms and clearing off injured or dead cells and tissues of the body (Oyewo et al. 2013; Faluyi and Agbede 2018). Similarly, the MCV and MCHC of the birds obtained in this study on the ranges of $169.70-350.00 \mathrm{fl}$ and $32.43-33.31 \mathrm{~g} / \mathrm{dl}$, respectively were above the reported range of $127 \mathrm{fl}$ and $29 \mathrm{~g} / \mathrm{dl}$, respectively as reported by Mitruka and Rawnsley (1977).

The inclusion of FTCPHM above 10\% recorded lowest values and this indicates that inclusion above this level may have a detrimental effect on the physiological functions of the birds which could arise from the effect of theobromine and other anti-nutrients contained in FTCPHM at higher levels. Similarly, the findings of Aro et al. (2012) using MFCSR in broilers were closely in agreement with the result of this study.

To assess the metabolic status of an animal, the serum metabolites levels are important indicators to verify (Neufingerl et al. 2013). In this study, most of the serum metabolites measured were not statistically influenced by FTCPHM except cholesterol, total protein, AST and ALT. Cholesterol, a high molecular weight sterol is used in the body as raw material for the therapeutic process (Oloruntola et al. 2018) useful in the normal role of the brain and it is an essential constituent of the cell membrane including organelles inside the cell. The present study shows the effect of FTCPHM inclusion levels on cholesterol level, though falling within the normal range for healthy chicken did not follow a well- defined trend. Globulin is important information of blood protein which when present in very low concentration could result in high mortality rate (Adegbenro et al. 2016). Sekine et al. (2013) reported that albumin concentration in serum is predicated on their factors that are independent of nutrition such as infections, liver function, kidney disease, trauma and hydration status which the result of this study clearly shows that none of these extra- nutritional factors had considerable effects on the birds as indicated in the serum antioxidants status of the birds as supported by Aro et al. (2012); Oloruntola et al. (2018) who used MFCSR. 15\% FCPHM inclusion in broiler reduced significantly compared to the rest of the diets which signifies the possible presence of some bioactive compounds in FCPHM which impaired fat absorption and consequent fat reduction. The reduced HDL (good cholesterol) and increased LDL (bad Cholesterol) as determined in the result supported the claimed of impaired fat absorption and are also of health benefits to the consumers, especially those predisposed to heart diseases. The inclusion of FCPHM in the diets vis- $a$ - vis decreased uptake of cholesterol or increased loss or catabolism of cholesterol (Peter and Susan 1999).

ALT and AST are important in the diagnosis of heart liver diseases and also the transamination in the metabolism of specific amino acids. The enzyme (ALT) results in this study were affected by the level of FTCPHM inclusion in the diets and followed a definite pattern. This is not consistent with the report of Oloruntola et al. (2018) where the MFCSR inclusion did not precipitate any effect on ALT of rabbits. The report by Aro et al. (2012) findings using MFCSR in broiler birds is in agreement with this present study.

\section{Conclusion}

This study tends to show that the inclusion of FTCPHM above $10 \%$ may have an adverse effect on the birds because of the theobromine effect. Additional research is needed to find further techniques of processing cocoa pod husk so that its theobromine content could be further reduced since it affects the bioavailability of nutrients to broilers above $10 \%$.

\section{Abbreviations \\ ADFI: Average Daily Feed Intake; ADWG: Average Daily Weight Gain; ALT: Alanine Aminotransferase; AST: Aspartate Aminotransferase; FTCPHM: Fungi Treated Cocoa Pod Husk Meal; MCH: Mean Corpuscular Hemoglobin; MCHC: Mean Cell Hemoglobin Concentration; MCV: Mean Cell Volume; PCV: Packed Cell Volume; RBC: Red Blood Cell; TFI: Total Feed Intake; TWG: Total Weight Gain; WBC: White Blood Cell}

\section{Acknowledgements}

I hereby acknowledge Prof. J. O. Agbede, Drs M. Adegbenro and A. O. Ayeni for planning, designing and supervising this work. 


\section{Funding}

Not Applicable.

\section{Availability of data and materials}

The data that support the findings of this study are available from Akanbi $\mathrm{O}$. M. but restriction applies to the availability of the data, which were used under license for the current study, and so are not publicly available. Data are however available from the author upon reasonable request and with permission of Akanbi O. M.

\section{Authors' contributions}

AOM analyzed the collected data and wrote the manuscript. AOM was the principal author who was responsible to manage all activities of the experiment and worked in the execution of trial and also involved in data collection and interpretation. All authors read and approved the final manuscript.

\section{Ethics approval and consent to participate}

Not applicable.

\section{Consent for publication}

Not applicable.

\section{Competing interests}

The author declares that they have no competing interests.

\section{Publisher's Note}

Springer Nature remains neutral with regard to jurisdictional claims in published maps and institutional affiliations.

\section{Received: 19 February 2019 Accepted: 19 March 2019}

Published online: 03 April 2019

\section{References}

Adamafio NA, Ayombil F, Tano-Debrah K (2011) Microbial detheobromination of cocoa (Theobroma cacao) pod husk. A J Biochem 6(2):200-207

Adegbenro M, Agbede JO, Onibi GE, Aletor VA (2016) Composite leaf meal: effects on haematology and biochemical indices of growing pigs. Arch Zootec 19(2):65-69

Adegbenro M, Ayeni AO, Agbede JO, Onibi GE, Aletor VA (2017) Performance characteristics of broiler chickens fed composite leaf meal as an alternative premix. Anim Res Inter 14(3):2883-2891

Adegbola AA, Omole TA (1973) A simple technique for preparing cocoa discarded bean-meal for use as livestock feed. N. Agric J 10(1):72-81

Adeyemo GO, Ajayi AO, Longe OG, Olubamiwo O (2015) Gut morphology and internal organs of broiler birds fed graded levels $\mathrm{f}$ bio- detheobromized cocoa pod bean shell (CBS) based diets. Am J Exp Agric 5(2):172-177

Adeyeye SA, Agbede JO, Aletor VA, Oloruntola OD (2017) Processed cocoa (Theobroma cacao) pod husk in rabbits diets: effects on haematological and serum biochemical indices. A J Adv Agric Res 2(4):1-9

Adeyeye SA, Agbede JO, Aletor VA, Oloruntola OD, Ayodele SO, Ahaotu EO (2016) Effects of rumen liquor fermentation on the proximate composition and antinutritional factors of ash- extract treated cocoa. (Theobroma cacao) pod husks, Proceedings of 21st Annual Conference of Animal Science Association of Nigeria, pp 18-22 Port Harcourt Supplementary 1:52-55

Akanbi OM (2019) Effect of Telfaira occidentalis leaf extract on the growth and health implications of Japanese quails. Disc Nat 13:29-35

Aro SO, Agbede JO, Dairo OO, Ogunsote E, Aletor VA (2012) Evaluation of fermented cassava tuber wastes in broiler chickens feeding. Arch Zootech 15(3):49-60

Asafa, A.R, Ologhobo, A.D. and Adejumo, I.O. (2012): Effect of catfish waste meal on performance characteristics and nutrient retention of broiler finishers. Int. J. Poult. Sci. 11:496-499.

Bedford M (2000) Removal of antibiotic growth promoters from poultry diets: implications and strategies to minimize subsequent problems. W Poult Sci J 56:347-367

Chineke CA, Ologun AG, Ikeobi CON (2006) Haematological parameters in rabbit breeds and crosses in humid tropics. Pak J Bio Sci 9(11):2102-2106

Eghosa OU, Rasheed AH, Martha O, Luqman AA (2010) Utilization of cocoa pod husk $(\mathrm{CPH})$ as a substitute for maize in layers mash and perception of poultry farmers in Nigeria. Inter J Sci Nat 1(2):271-275
Faluyi OB, Agbede JO (2018) Immunostimulatory activity of aqueous leaf extract of Moringa oleifera in broiler chickens. Intern J Env Agric Biotech 3(1):49-54

FAO (2008) The state of food and agriculture. FAOSTAT production database. Food and Agriculture Organization of the United Nation, Rome

Hamzat RA, Babatunde (2006) Utilization of cocoa bean shell as a feed ingredient for broiler chickens, Proceeding of the $15^{\text {th }}$ Internal Cocoa Research Conference, Costa Rica, pp 84-86

Isika MA, Nsa EE, Ozung PO (2012) Replacement value of processed cocoa bean meal for groundnut cake in rations for fryer rabbits. J Sus Tech 3(1):118-127

Iyayi EA, Olubamiwa O, Ayuk A, Orowvegodo S, And Ogunaike EF (2001) Utilization of urea treated and untreated cocoa pod husk based diets by growing pigs: an on-farm study. Tropi 19(3):101-104

Mazzafera P (2002) Degradation of caffeine by microorganisms and potential use of decaffeinated coffee husk and pulp in animal feeding. Sci Agric 59(4):815821

Mitruka BM, Rawnsley HM (1977) Clinical biochemical and haematological references values in normal experimental animals, vol 88. Masson Publishing, U.S.A. Inc, pp 46-47

National Research Council (1994) Nutrients requirements of poultry, 9th edn. National Research Council, Washington

Neufingerl N, Zebregs YE, Schuring EAH, Traubwein EA (2013) Effects of cocoa and theobromine consumption on serum HDL-cholesterol concentrations: a randomized controlled trial. Am J Clin Nutr 97:1201-1209

Nortey TN, Ewusi I, Kpogo LA, Oddoye EOK, Naazie A (2015) Cocoa pod husk with enzyme supplementation is a potential feed ingredient in broiler diets. Live Res Rur Dev 27(5):8-13

Nworgu FC, Adebowale EA, Oredein OA, Oni A (1999) Prospect and economics of broiler production using two plant protein sources. Trop J Anim Sci 2:159-166

Ogunsipe MH, Balogun KB, Oladepo AD, Ayoola MA, Arikewuyo MT (2017) Nutritive value of cocoa bean shell meal and its effect on growth and haematology of weaning rabbits. N J Agric F Env 13(1):23-28

Oloruntola OD, Agbede JO, Onibi GE, Igbasan FA (2016a) Replacement value of rumen liquor fermented cassava peels for maize in growing rabbit diet. Arch Zootech 65(249):89-97

Oloruntola OD, Agbede JO, Onibi GE, Igbasan FA, Ogunsipe MH, Ayodele SO (2018) Rabbits fed fermented cassava starch residue II: enzyme supplementation influence on performance and health status. Arch Zootech 67(260):588-595

Oloruntola OD, Ayodele SO, Agbede JO, Oloruntola DA, Ogunsipe MH, Omoniyi IS (2016b) Effect of Alchorea cordifolia leaf meal and enzyme supplementation on growth, haematological, immunostimulatory and serum biochemical response of rabbits. A J Bio Life Sci 5(2):190-195

Olubamiwa O, Akinwale TO (2000) Partial placement of maize with cocoa husks meals in layers mash: an on-farm experience. J Food Tech Afr 5(2):62-63

Omoifo CO (2011) Rhizopus stolonifer exhibits dimorphism. Afr J Biotech 10(20): 4269-4275

Oyewo, E. B., Adetutu, A., Ayoade, A. And Akanni, M. A. (2013). Repeated oral administration of aqueous leaf extract of Moringa oleifera modulated immunoactivities in Wister rats. J Nat Sci Res 3 (6): 100-109

Oyinloye MA (2013) Monitoring spatial growth of educational institution using geographical information system: a focus on Federal University of Technology, Akure, Nigeria. Am J Hum Soc Sci 1(3):163-173

Peter ML, Susan CEF (1999) Interpretation of laboratory results. Aus Vet Pra 21(4): 188-193

Saki, A. A., Hemati- Martin, H. R., Zamari, P. And Mirzaaghatabar (2011). Non starch polysaccharides and broiler responses. W App Sci J 15 (2): 192-198

Saliu JA, Elekofehinti OO, Komolafe K, Oboh G (2012) Effects of some green leafy vegetables on the hematological parameters of diabetic rats. Scholars Research Library. J Nat Pro and Pla Res 2(4):7-15

Sarojini TR (2005) Modern Biology, 3rd edn. Africana First Publisher Limited Nigeria

Sekine S, Terada S, Aoyama T (2013) Medium chain triacylglycerol suppresses the decrease of plasma albumin level through the insulin-Akt-mTOR pathway in the livers of malnourished rats. J Nutr Sci Vit 59(2):123-128

Shirzadi H, Moravej H, Shivazad M (2009) Comparison of the effects of different kinds of non-starch polysaccharides enzymes on the performance, water intake, litter moisture and jejuna digesta viscosity of broiler fed barley-based diets. J Food Agric Env 7(3\&4):615-619

SPSS (version 23.0). SPSS Software products, Marketing Department, SPSS Inc. Chicago 
Swenson MJ (1977) Dukes' physiology of domestic animals, 9th edn. Cornstock Publishing Associates, Cornell University Press, Ithaca, London, pp 14-34

Teguia A, Endeley HNL, Beynen AC (2004) Broiler performance upon dietary substitution of cocoa husks for maize. Inter J Poult Sci 3:779-782

Zakaria, H. A. H., Jalal, M. A. R. And Jabarin, A. S. (2008): Effect of exogenous enzymes on the growing performance of broiler chickens fed regular corn/ soybean-based diets and the economics of enzyme supplementation. Pak $J$ Nutr 7 (4):534-539

\section{Submit your manuscript to a SpringerOpen ${ }^{\odot}$} journal and benefit from:

- Convenient online submission

- Rigorous peer review

- Open access: articles freely available online

High visibility within the field

- Retaining the copyright to your article

Submit your next manuscript at $\boldsymbol{\wedge}$ springeropen.com 